\title{
A computational analysis of Turkish makam music based on a probabilistic characterization of segmented phrases
}

\author{
Barış Bozkurt $^{\mathrm{a} *}$ and Bilge Karaçalı ${ }^{\mathrm{b}}$ \\ ${ }^{a}$ Electrical and Electronics Engineering Department, Bahçeşehir University, Istanbul, Turkey; \\ ${ }^{b}$ Electrical and Electronics Engineering Department, Izmir Institute of Technology, Izmir, Turkey
}

(Received 29 August 2013; accepted 19 May 2014)

\begin{abstract}
This study targets automatic analysis of Turkish makam music pieces on the phrase level. While makam is most simply defined as an organization of melodic phrases, there has been very little effort to computationally study melodic structure in makam music pieces. In this work, we propose an automatic analysis algorithm that takes as input symbolic data in the form of machine-readable scores that are segmented into phrases. Using a measure of makam membership for phrases, our method outputs for each phrase the most likely makam the phrase comes from. The proposed makam membership definition is based on Bayesian classification and the algorithm is specifically designed to process the data with overlapping classes. The proposed analysis system is trained and tested on a large data set of phrases obtained by transferring phrase boundaries manually written by experts of makam music on printed scores, to machine-readable data. For the task of classifying all phrases, or only the beginning phrases to come from the main makam of the piece, the corresponding F-measures are .52 and .60 respectively.
\end{abstract}

Keywords: maqam; makam; phraseology; computational musicology; Turkish music

\section{Introduction}

Makam/maqam/mugam/ . . is a key concept in music of a large geographical region (including many north African, middle eastern, and Asian countries), and it is very rarely studied using computational methods. In this study, we consider computational analysis of the traditional makam music of Turkey, mainly analysing symbolic data presented in the form of machine-readable scores.

A large number of different descriptions are available for the makam concept in Turkish music literature. Some examples are: "Makam is a process of occurrence. It is a specific form of a musical scale that characterizes itself by an organization of intervals and various constitutive relations" (Yekta 1924); "the feature that is created by the relation of pitches of a scale or melody and the tonic and/or dominant" (Arel 1968); "a practical melody theory, grouping melodies by families or categories that are distinguished by the use of careful microtonal inflections of certain tones according to custom, together with idealized notions of melodic contour" (Stubbs 1994, 1). A list of definitions and a review of makam music theories are available in Can (1993); Elsner and Pennanen (1997); Ayangil (2001); Öztürk (2011); and Yöre (2012), which show that the concept of makam has been considered using basically two different conceptualizations: "a scale-centred

*Corresponding author. Email: baris.bozkurt@bahcesehir.edu.tr 


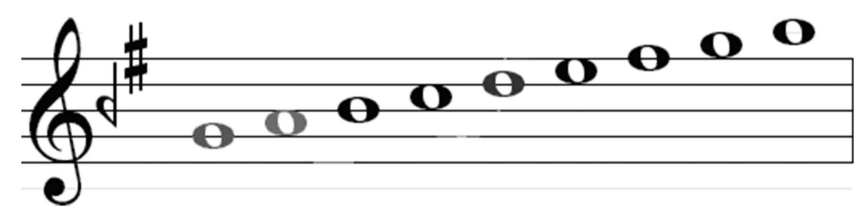

Figure 1. Scale for makamlar Hüseyni, Neva, Muhayyer, Gülizar, Gerdaniye, Tahir. Tonic is note Dügah (A) and leading tone is note Rast $(\mathrm{G})$.

approach" and "a melody-centred approach." Powers and Wiering (n.d) interpret the makam concept as a mode in the sense of a particularized scale or generalized tune, in the middle of a continuum between scale and tune on its two ends.

While the current "official" theory of Turkish makam music as presented by Arel (1968) considers scales and hierarchy of certain tones as a central point for describing makamlar (plural of makam), this formulation has been subject to criticism by many musicologists (Ay and Akkal 2008). For instance, Öztürk (2011) considers this scale-centred approach as the result of a Westernization process and claims that a melody-centred approach should be preferred. A large part of makam literature stresses the importance of melodic progression, "seyir." As outlined in (Ayangil 2001; Çelik 2001), most of the historical texts also present the makamlar by descriptions of melodic progression rules. There are typically three types/classes of progressions stated in almost all theory books: ascending, ascending-descending (or alternatively "seyir in the mid-register"), and descending which describes the average shape of the overall melodic progression.

In today's Turkish makam music practice, we find many makamlar sharing the same scale and tonic and differing only in melodic progression. Figure 1 presents the scale used in six different makamlar, which are mainly differentiated by their melodic progression.

Given the importance of melodic organization, it is interesting to note that computational analysis efforts dedicated to analysis of makam music melodies is limited to a few attempts at finding the most repeated motifs in score databases. (We present a review of these studies in Section 2.2. An extensive review of computational studies on Turkish makam music can be found in Bozkurt, Ayangil, and Holzapfel 2014.) Finding the most repeated motifs, however, has very little use in analysis of makam music: makamlar share same/similar paths with other makamlar and a piece in one makam contains phrases (sometimes even stereotyped phrases) of another makam. For instance, a piece in makam Muhayyer may contain phrases also used in pieces from makam Hüseyni. Musicological studies for analysis of makam music melodies mainly target assigning tetra/penta-chord labels or makam labels to phrases while there is one main makam assigned for the piece as an entity. The piece can contain phrases borrowed from different makamlar. However, no agreed methodology is available to date to perform assignment of a phrase to a specific makam.

In this paper we address the challenge of studying makam membership ${ }^{1}$ of a phrase and further propose an analysis method based on a membership measure that outputs a representation of the context change within a piece. To this end, we have designed a score database of manually segmented phrases in 15 different makamlar. The phrase boundaries are manually inserted by experts of makam music on printed scores and then transferred to machine-readable data using specifically designed editing software. These manually segmented phrases were then assumed to come from overlapping classes. As stated previously, two different makamlar may use the same

\footnotetext{
${ }^{1}$ Makam membership refers to the probability of an entity (phrase in our case) being assigned to a specific makam. While we consider it here as a measure of makam specificity of a phrase, its use in music practice is not well defined. The relevance of makam membership in music practice is an open topic for ethnomusicology and needs dedicated field work.
} 
scale. Pieces from these makamlar may include very similar phrases and only differ in overall melodic progression and/or emphasis levels of certain scale degrees.

The original contributions of this paper are the makam membership definition based on Bayesian classification, the algorithm to process data with overlapping classes, and the method proposed for analysis of a piece. We showed through tests on a database containing 199 pieces from 15 different makamlar that an accuracy of 0.5208 is obtained for all phrases and an accuracy of 0.6021 is obtained on the first four phrases of the pieces. Since the pieces involve phrases from different makamlar (especially in makam transition parts), we do not expect an assignment of each phrase to the makam of the piece. Hence, the accuracy values presented should not be considered as a quantitatively exact measure of algorithm efficiency.

Our paper is structured as follows. First, a review of analysis for makam music melodies is presented in Section 2. Description of the symbolic makam music dataset used in this study is presented in Section 3. Section 4 is dedicated to the proposed computational method: the membership definition, implementation, and the methodology of the resulting phrase recognition algorithm. Section 5 presents results and discussions.

\section{Analysis of makam music melodies}

\subsection{Analysis methods in musicology resources}

"Analysis of Turkish makam music ${ }^{2}$ melodies" in musicology literature mainly refers to specifying/listing tetra/penta chords (sorted note sequences that constitute a subdivision of a scale, cins (Turkish), jins, ajnas (Arabic)) used for each melodic segment (e.g. Kılınçarslan 2006; Eroy 2010; Gönül 2010). This approach, though criticized by many scholars ${ }^{3}$ for its low usefulness, is considered as a way to represent context change throughout the piece. While almost every scholar agrees that understanding the makam concept necessitates studying context changes in melodic progressions in pieces or improvisations, there is no methodology agreed upon for such a representation and ways to interpret it.

Figure 2 shows an example of analysis performed by a makam theory teacher from the Istanbul Technical University Turkish Music Conservatory (the oldest and biggest Turkish music conservatory today). Each segment is tagged with the lowest note of the main chord used (Neva, Buselik, Dügah, etc.) and the name of the chord (Buselik, Nişabur, Hicaz, etc.). In our personal communication with various local masters to collect similar data, they refused to perform the task, arguing that listing tetra-chords for each phrase is useless since what matters is the function and it would be different in the context of different makamlar. Ederer (2011) proposes similar but a clearer representation (since the link between the chord and the makam is also stated for makam transitions) in a table form. Again, the aim is to represent context change within the piece or improvisation.

\subsection{Review on computational methods for melodic analysis of makam music}

Computational analysis literature on Turkish makam music melodic phrases is limited to studies on symbolic data due to the difficulties involved in audio analysis. Heterophony (simultaneous variation of a single melody by several instruments or voices) and frequent use of ornamentations

\footnotetext{
2 The term "makam" mainly refers to a modality system and is used in many genres (such as folk, art and various popular music genres). Here, we mainly consider a collection including Ottoman/Turkish traditional/classical/art music ("geleneksel/klasik Osmanlı/Türk (sanat) musikisi") and folk music pieces.

${ }^{3}$ Private communication with experts including Reha Sağbaş, Ruhi Ayangil, Korkutalp Bilgin, and Cem Çırak, 2013.
} 
Usul: Ağırçenber (24/2)

\section{Düşmesin Miskin Gönüller Hicaz-Hümâyûn Beste}

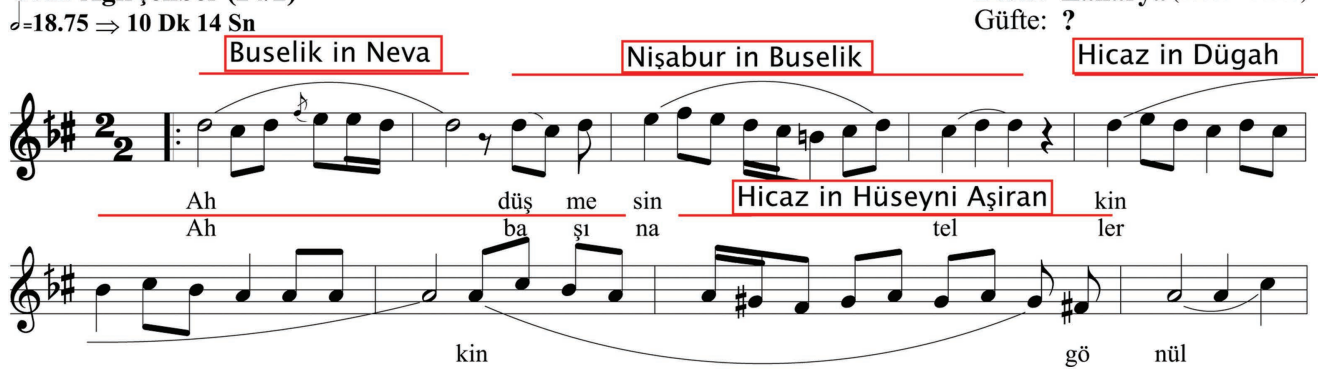

Figure 2. Analysis example by an expert in Turkish makam music education.

are the main obstacles for reliable estimation of the fundamental frequency, hence analysis on melodies, directly on audio signals.

In most of the computational studies on symbolic data, one of the important deficiencies is representation of microtonal intervals of Turkish makam music. Arel theory (Arel, 1968) uses a 24-tone (per octave) Pythagorean system for tuning. Mismatch of the Arel theory with the practice is well known (Bozkurt et al. 2009) but still, it provides the most commonly used notation system today. Large archives containing scanned images of Turkish makam music written in Arel notation are publicly available (e.g.: http://notaarsivleri.com/) and commonly used in music circles today.

Until very recently, computational studies had to rely on data collected using notation software designed mainly for equal tempered representations. Popular MIDI (Musical Instrument Digital Interface ${ }^{4}$ ) editors or other 12-Tet (tone equal temperament) notation software have been used to collect machine-readable symbolic data for Turkish makam music. It had been common practice to omit Turkish makam music specific accidentals and perform analysis on the resulting data quantized to 12-Tet (e.g. Gedik et al. 2005). In various other studies, software capable of including Turkish makam music specific accidentals on staff were used to create score databases and the scores were further exported in XML format for computational analysis. Unfortunately these studies provide very little information about how Turkish music accidentals have been processed (if discarded or not) (e.g. Yener 2004; Yener and Aksu 2004).

It is only very recently that microtonal notation editor software (such as Mus2: http://www.mus2.com.tr/) has been introduced and a few projects on data collection have been launched. Recently, a large collection of machine-readable microtonal scores has been made publicly available (Karaosmanoğlu 2012) and part of our work (Bozkurt, Ayangil, and Holzapfel 2014 ) is dedicated to contributing to such data collection efforts. The data used in our study are collected using software dedicated to Turkish makam music.

It is interesting to note that many computational studies for analysis of Turkish makam music use pitch class and/or interval histograms as features of melodic progression (Eroy 2010; Gönül 2010; Sümbüllü and Albuz 2011). Yener (2004) studied automatic detection of stereotyped phrases for makam in solo improvisations and in Turkish folk pieces (Yener and Aksu 2004). In these studies, standard statistical measures were obtained (using SPSS) for note sequences and the most frequent three- to eightnote patterns were listed as a result. A similar study was carried out by Müezzinoğlu (2004), this time using SQL (Structured Query Language) for statistical analysis for a specific type of Turkish folk music, zeybek. This study also presents note transition probabilities for the

\footnotetext{
${ }^{4}$ The complete MIDI 1.0 detailed specification is available from www.midi.org
} 
given database. Sümbüllü and Albuz (2011) also used XML data and SQL, SPSS, and Excel to gather statistical information. None of these studies consider studying melodic progression and context change within pieces. The fact that makamlar share common phrases/paths and pieces contain phrases from various makamlar is simply discarded.

In computational analysis literature on other music traditions, a large group of work is dedicated to melodic pattern extraction with the aim of efficient song retrieval. Comprehensive review of this domain can be found in Rolland (1999), and Meredith, Lemstrom and Wiggins (2002). Most of these studies are based on representations that combine melodic and rhythmic dimensions (Conklin 2001, 2010; Lartillot and Ayari 2009) and pattern discovery leads to capturing melodic patterns, rhythmic patterns, and combinational patterns repeated in large databases. Within the context of analysis of Turkish makam music melodies, if the aim is not limited to retrieval of a specific pattern, repeated pattern extraction would only become informative when detected patterns are related to makam music specific concepts. The only computational work (we could find) to study the link between makam concepts and melodic segments (within Tunisian maqam music) is Lartillot and Ayari (2009). However, their work is limited to exposing how melodic boundaries and maqamspecific information are related based on listeners' performance of segmentation. Şentürk (2011) used Variable-Length Markov Models (VLMMs) to study the predictability of improvised Turkish folk melodies. Apart from representing the pitch scale by 17 notes in an octave, no makam music-specific information is included in the system design. Şentürk's conclusion is that the melodies are highly predictable.

Gündüz and Gündüz (2005) and Tarikci (2010) studied the fractal dimension of notes sequences in Turkish makam music pieces. In these studies, symbolic data in the Arel notation system is used and fractal dimension is computed as a measure of complexity of melodies. Tarikci reported that some makamlar exhibit more irregular patterns than others and "Turkish art music songs show a fractal behavior.” In Gündüz and Gündüz (2005), the authors propose various graphical representations (and the underlying mathematical models) for makam music melodies including a radial distribution of notes, animal diagrams, etc. They demonstrate that these representations have some potential in performing structural analysis via visual detection of similarities in different sections of a piece. The design of an algorithm for performing such an analysis in an automatic way is not considered.

In the computational analysis literature, to the best of our knowledge, no study tackles the problem of linking phrases of a piece to a pool of different makamlar although it is well-known that a piece in one makam contains melodies from other makamlar. All studies mentioned above are based on the assumption that the makam of the piece defines the makam of each phrase in the piece. While the masters of this music emphasize the importance of analysis to study the context change within a piece, no computational study targets this either. As a result, the literature does not provide us any means to perform automatic analysis of melodic phrases of a given Turkish makam music piece.

\section{The data}

Our symbolic database is comprised of scores written using the Mus2 microtonal notation software (http://www.mus2.com.tr/) and further converted to the machine readable text format of SymbTr (Karaosmanoğlu 2012). We have chosen to focus on the more popular 15 makamlar, also taking into consideration the sorted list of available scores in each makam in Çevikoğlu (2007).

Scores were printed on sheets and given to an expert. The expert was asked to indicate phrase boundaries, as he would do it for analysis based on melodies. There was no time pressure, the 

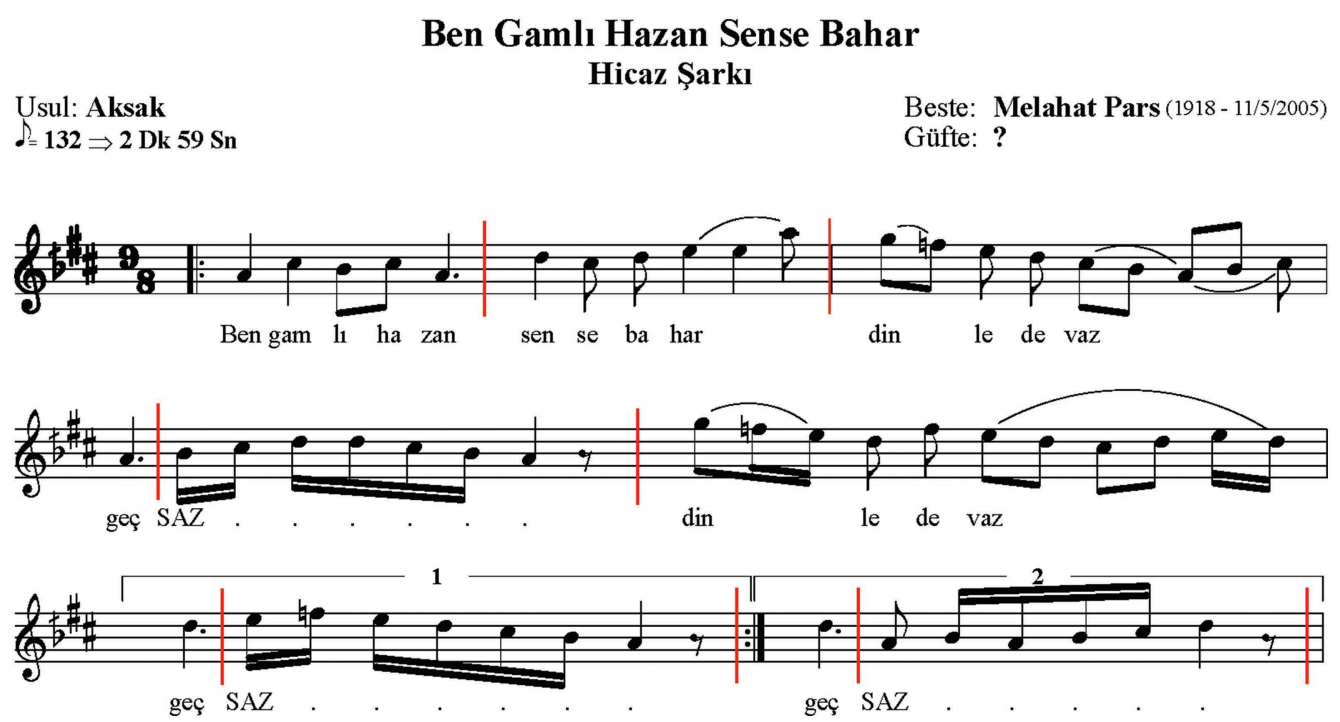

Figure 3. Example excerpt of a score from the database, which includes melodic phrase boundaries labelled by an expert.

Table 1. Machine readable text version of the example in Figure 3.

\begin{tabular}{rrllccccrcrc}
\hline Index & Code & Note53 & NoteAE & Comma53 & CommaAE & Num. & Denum. & Ms & LNS & VelOn & Syll \\
\hline 1 & 9 & La4 & A4 & 305 & 305 & 1 & 4 & 909 & 95 & 96 & Ben \\
2 & 9 & Do5\#4 & C5\#4 & 322 & 322 & 1 & 4 & 909 & 95 & 96 & gam \\
3 & 9 & Si4b4 & B4b4 & 310 & 310 & 1 & 8 & 455 & 95 & 96 & li \\
4 & 9 & Do5\#4 & C5\#4 & 322 & 322 & 1 & 8 & 455 & 95 & 96 & ha \\
5 & 9 & La4 & A4 & 305 & 305 & 3 & 8 & 1364 & 95 & 96 & zan \\
6 & 53 & & & 0 & 0 & 0 & 0 & 0 & 0 & 0 & sen \\
7 & 9 & Re5 & D5 & 327 & 327 & 1 & 4 & 909 & 95 & 96 & sen \\
8 & 9 & Do5\#4 & C5\#4 & 322 & 322 & 1 & 8 & 455 & 95 & 96 & se \\
9 & 9 & Re5 & D5 & 327 & 327 & 1 & 8 & 455 & 95 & 96 & ba \\
10 & 9 & Mi5 & E5 & 336 & 336 & 2 & 4 & 1818 & 95 & 96 & har \\
11 & 9 & La5 & A5 & 358 & 358 & 1 & 8 & 455 & 95 & 96 & 0 \\
12 & 53 & & & 0 & 0 & 0 & 0 & 0 & 0 & 0 \\
13 & 9 & Sol5 & G5 & 349 & 349 & 1 & 8 & 455 & 99 & 96 & din \\
14 & 9 & Fa5 & F5 & 340 & 340 & 1 & 8 & 455 & 95 & 96 \\
\hline
\end{tabular}

expert could do segmentation any time within a three-month period, and he could use his instrument when he liked. His segmentations were manually exported to the format in Table 1 using a specially designed interface. In Figure 3 and Table 1, we present an example as tagged by the expert and as shown in the machine-readable format.

In the machine readable format, segmentation is represented by lines indicating the code (second column in Table 1) as 53. The data set is composed of 199 pieces manually segmented into 8065 phrases in 15 makamlar (number of phrases in each makam is available in the confusion matrix presented in Table 5 later and the number of pieces is presented in Table 2).

While a detailed explanation of the SymbTr format can be found in (Karaosmanoğlu 2012), we present a short summary here. "Code" signifies a normal note (\#9) or ornamentation or segmentation (\#53). The most commonly used ornamentation codes are as follows: \#7 for tremolos, \#8 for acciaccatura, \#12 for trills, and \#23 for mordent. "Note53" and "Comma53" include the pitch information in a 53Tet resolution and "NoteAE" and "CommaAE" include the pitches specified as in the Arel theory. The latter is obtained by direct conversion of staff notation into text where 
Table 2. Number of pieces in each makam.

\begin{tabular}{lcccccccc}
\hline makam & Acemaşiran & Beyati & Buselik & Hicaz & Hicazkar & Hüseyni & Hüzzam & Mahur \\
\hline \# pieces & 9 & 3 & 8 & 34 & 14 & 24 & 18 & 7 \\
\hline makam & Uşşak & Nihavent & Rast & Saba & Muhayyer & Segah & Kürdilihicazkar \\
\hline \# pieces & 12 & 7 & 11 & 7 & 11 & 13 & 21 \\
\hline
\end{tabular}

the former is a corrected version of the pitch by master musicians. Here, "Note" stands for "name of the pitch" and "comma" stands for the interval of the pitch with respect to $\mathrm{C}_{1}$ (represented in Holderian/Mercator commas obtained by equal division of an octave by 53). "Num.", "Denum.", and "Ms" columns specify the duration. "Syll." contains the lyrics. "VelOn" is used to specify velocity dynamics. "LNS" (Legato / Normal / Staccato) indicates how tied or detached the notes are. This text representation facilitates viewing the content of the data without need of any specific program but just a text editor and easy data access (compared with, for example, microtonal MIDI files).

\section{Makam membership of a phrase and its use in melodic progression analysis of individual pieces}

In this section, we describe the methodology used to determine the makam memberships of individual phrases identified manually by expert musicians on the makam music dataset described in the previous section. We begin by elucidating the mathematical details of the membership function that assigns a given phrase to the most likely makam. Next, we provide details on the computation of the model-specific parameters that define the membership function from the available phrase data. Finally, we formulate the procedure we have used to determine the makam membership of all phrases in our database using the derived membership function along with the performance measures employed to evaluate the accuracy of the resulting makam assignments.

\subsection{Membership function}

Phrases can be represented as an ordered sequence of notes at a specific pitch and with a specific duration. This suggests defining a musical phrase $s$ consisting of $\ell_{s}$ notes as an ordered collection of pairs

$$
s=\left\{\left(f_{i}, d_{i}\right)\right\}
$$

where $f_{i}$ and $d_{i}$ denote the pitch and the duration of the $i$ th note in the phrase, respectively, for $i=1,2, \ldots, \ell_{s}$. The pitch information is specified in Holderian/Mercator commas and the duration is specified in full notes. As a membership function, we seek a map $\mathbf{M}$ defined by

$$
\mathbf{M}(s)=m
$$

that links a given phrase $s$ with one of the possible makamlar, denoted by $m$.

In order to derive a membership function, we adopt a Bayesian approach and exploit the probabilistic relationship between the phrases extracted from the musical pieces and the makamlar according to which the pieces themselves were written. To this end, we have considered the random variables $S$ and $M$ to represent the musical phrase and the makam of the corresponding 
piece, respectively. In this setting, the optimal membership function can be expressed as

$$
\mathbf{M}^{\text {opt }}(s)=\arg \max _{m} \operatorname{Pr}\{M=m \mid S=s\}
$$

where $\operatorname{Pr}\{M=m \mid S=s\}$ denotes the conditional probability ${ }^{5}$ of the makam $m$ given the phrase $s$. Using Bayes' rule, we obtain

$$
\operatorname{Pr}\{M=m \mid S=s\}=\frac{\operatorname{Pr}\{S=s \mid M=m\} p_{M}(m)}{p_{S}(s)}
$$

with the probability mass functions of the phrases and the makamlar expressed by $p_{S}(s)$ and $p_{M}(m)$, respectively, along with $\operatorname{Pr}\{S=s \mid M=m\}$ representing the conditional probability of the phrase $s$ given the makam $m$. Note that the probability mass function $p_{M}(m)$ refers to the occurrence rate of the different makamlar over all phrases, while $p_{S}(s)$ represents the more esoteric probability of observing a specific phrase $s$ in all of makam music, with

$$
p_{S}(s)=\sum_{m} \operatorname{Pr}\{S=s \mid M=m\} p_{M}(m) .
$$

Since they figure as a constant multiplicative factor in the expression for the conditional probability $\operatorname{Pr}\{M=m \mid S=s\}$ and can be obtained from the conditional probabilities $\operatorname{Pr}\{S=s \mid M=m\}$ for the different makamlar $m$ along with $p_{M}(m)$, the exact values of $p_{S}(s)$ are inconsequential to the makam membership assignment of the phrases. The challenge in formulating the membership function thus rests on expressing the conditional probability $\operatorname{Pr}\{S=s \mid M=m\}$ and its natural logarithm. We propose two different quantities for this conditional probability, and consequently two different membership functions. The first quantity, expressed in equation (2), ignores durations. Equations (1) and (2) together give the membership function in equation (3) without durations. The second proposed quantity for the conditional probability, expressed indirectly in equation (4) via the natural logarithm, takes durations into consideration. Equations (1) and (4) together give the membership function in equation (5) which does consider durations. After these, we consider several other membership functions as well.

In this work, we have used pitch distributions of the phrases to characterize the probability structure linking them to different makamlar. This allows us to decompose the conditional probability $\operatorname{Pr}\{S=s \mid M=m\}$ as

$$
\operatorname{Pr}\{S=s \mid M=m\}=\prod_{i=1}^{\ell_{s}} p_{F \mid M}\left(f_{i} \mid M=m\right)
$$

where $p_{F \mid M}(f \mid M=m)$ represents the probability of observing a note at pitch $f$ in makam $m$, with $F$ denoting the random variable of pitch. This leads to the membership function

$$
\mathbf{M}_{f}(s)=\arg \max _{m}\left(\log p_{M}(m)+\sum_{i=1}^{\ell_{s}} \log p_{F \mid M}\left(f_{i} \mid M=m\right)\right)
$$

using the natural logarithm function that makes it easier to handle small probability values. The argument to the maximum operator acts as a discriminant function that takes on separate values

\footnotetext{
${ }^{5}$ The conditional probability $\operatorname{Pr}\{\mathrm{A} \mid \mathrm{B}\}$ represents the probability of a chance event A given that the chance event $\mathrm{B}$ has occurred already. Note that this deviates from the probability $\operatorname{Pr}\{\mathrm{A}\}$ that does not take into account the occurrence of the event B. In this respect, the conditional probability incorporates the additional information from the event B to calculate the probability of A more accurately.
} 
for the different makamlar, and the assignment of the phrase $s$ is made to the makam for which this value is maximal.

Note that this decomposition disregards the joint probability structure of the notes $\left(f_{i}, d_{i}\right)$ as well as the specific order in which they come together to form a phrase, and considers only the number of times each pitch is visited during the phrase. The strong statistical inference from the pitch distributions of musical pieces to the underlying makam has been demonstrated in earlier works. Ünal, Bozkurt, and Karaosmanoğlu (2014) have studied the automatic makam classification problem using $n$-grams where they report that even 1-gram information, which corresponds to simply pitch class distributions, is highly discriminative. Gedik and Bozkurt (2010) and Ioannidis, Gómez, and Herrera (2011) have shown that pitch distributions can be effectively used for makam classification of audio data.

As an alternative, we also consider the following decomposition for a different log conditional probability

$$
\log (\operatorname{Pr}\{S=s \mid M=m\})=\frac{\ell_{s}}{\sum_{i} d_{i}} \sum_{i=1}^{\ell_{s}} d_{i} \log \left(p_{F \mid M}\left(f_{i} \mid M=m\right)\right)
$$

which takes into account the duration of the notes as well as their pitch. The multiplicative factor ensures that when all notes have equal duration, the earlier duration-independent expression is obtained.

Note that this decomposition captures the relationship between the notes $\left(f_{i}, d_{i}\right)$ and the phrase $s$ when the phrase is uniformly sampled in time for its total duration. To see this, consider the pitch signal $f(t)$ of a phrase $s$ defined as follows.

$$
f(t)= \begin{cases}f_{1} & \text { if } 0 \leq t<d_{1} \\ f_{2} & \text { if } d_{1} \leq t<d_{1}+d_{2} \\ \vdots & \vdots \\ f_{\ell_{s}} & \text { if } d_{1}+d_{2}+\ldots+d_{\ell_{s}-1} \leq t<d_{1}+d_{2}+\ldots+d_{\ell_{s}}\end{cases}
$$

The conditional probability $\operatorname{Pr}\{S=s \mid M=m\}$ can now be expressed as

$$
\begin{aligned}
\operatorname{Pr}\{S=s \mid M=m\} & =\prod_{k=1}^{\frac{\sum_{i} d_{i}}{\Delta t}} p_{F \mid M}(f(k \Delta t) \mid M=m) \\
& =\prod_{i=1}^{\ell_{s}}\left(\prod_{k=1}^{\frac{d_{i}}{\Delta t}} p_{F \mid M}\left(f_{i} \mid M=m\right)\right) \\
& =\prod_{i=1}^{\ell_{s}}\left(p_{F \mid M}\left(f_{i} \mid M=m\right)\right)^{\frac{d_{i}}{\Delta t}}
\end{aligned}
$$

where $\Delta t \ll 1$ denotes the sampling period, which is assumed to be an integer divisor of each $d_{i}$. Clearly, then,

$$
\log (\operatorname{Pr}\{S=s \mid M=m\}) \propto \sum_{i=1}^{\ell_{s}} d_{i} \log \left(p_{F \mid M}\left(f_{i} \mid M=m\right)\right)
$$

since $\Delta t$ becomes a constant dividing factor following the logarithm, and the alternative decomposition for $\log (\operatorname{Pr}\{S=s \mid M=m\})$ noted in equation (4) follows (up to a factor). 
The corresponding membership function then becomes

$$
\mathbf{M}_{f, d}(s)=\arg \max _{m}\left(\log p_{M}(m)+\frac{\ell_{s}}{\sum_{i} d_{i}} \sum_{i=1}^{\ell_{s}} d_{i} \log p_{F \mid M}\left(f_{i} \mid M=m\right)\right) .
$$

Note that the factor before the sum of logarithms serves to achieve equality of the membership functions in equations (3) and (5) when the note durations are equal. Given that the statistical relationship between the phrases and the makamlar can be expressed over the notes that make up a phrase, we have derived additional membership functions that capture different aspects of the underlying correlation structure. To this end, we have first expressed the conditional probability $\operatorname{Pr}\{M=m \mid F=f\}$ as

$$
\operatorname{Pr}\{M=m \mid F=f\}=\frac{p_{F \mid M}(f \mid M=m) p_{M}(m)}{p_{F}(f)}
$$

again using Bayes' rule, where $p_{M}(m)$ now represents the prior probability of the makam $m$ over all pitches observed in makam music. Then, the cumulative evidence expressed by the product

$$
\prod_{i=1}^{\ell_{s}} \operatorname{Pr}\left\{M=m \mid F=f_{i}\right\}=\prod_{i=1}^{\ell_{s}} \frac{p_{F \mid M}\left(f_{i} \mid M=m\right) p_{M}(m)}{p_{F}\left(f_{i}\right)}
$$

identifies to which makam $m$ the phrase $s=\left\{\left(f_{i}, d_{i}\right)\right\}$ should belong, as it is expected to attain larger values for the more plausible makams. This suggests the function

$$
\mathbf{M}_{f}^{\text {note }}(s)=\arg \max _{m}\left(\ell_{s} \log p_{M}(m)+\sum_{i=1}^{\ell_{s}} \log p_{F \mid M}\left(f_{i} \mid M=m\right)\right)
$$

as an additional membership function, using the natural logarithm to convert the product of probabilities into sums, and leaving the term due to the probabilities $p_{F}\left(f_{i}\right)$ out as they are the same for all makamlar and do not affect the assignment of the phrase into the more likely makam. Note that an immediate variation on $\mathbf{M}_{f}^{\text {note }}(s)$ can be obtained by factoring in the note durations to define yet another membership function $\mathbf{M}_{f, d}^{\text {note }}(s)$ as

$$
\mathbf{M}_{f, d}^{\text {note }}(s)=\arg \max _{m}\left(\ell_{s} \log p_{M}(m)+\frac{\ell_{s}}{\sum_{i} d_{i}} \sum_{i=1}^{\ell_{s}} d_{i} \log p_{F \mid M}\left(f_{i} \mid M=m\right)\right) .
$$

Following the reasoning that ties the makam assignment of a given phrase to the posterior probabilities of the different makamlar on the individual notes of the phrase further, we have also defined

$$
\mathbf{M}_{f}^{\text {ave }}(s)=\arg \max _{m}\left(p_{M}(m) \sum_{i=1}^{\ell_{s}} p_{F \mid M}\left(f_{i} \mid M=m\right)\right)
$$

and

$$
\mathbf{M}_{f, d}^{\text {ave }}(s)=\arg \max _{m}\left(p_{M}(m) \sum_{i=1}^{\ell_{s}} d_{i} p_{F \mid M}\left(f_{i} \mid M=m\right)\right)
$$

as two additional membership functions. In essence, $\mathbf{M}_{f}^{\text {ave }}(s)$ and $\mathbf{M}_{f, d}^{\text {ave }}(s)$ compute a linear average of the makam probabilities conditional on each note of the phrase, weighted equally in the former and according to the note durations in the latter. 
Note that computation of the different membership functions described above requires the availability of several conditional probabilities. Details of the estimation of these probability distributions along with the remaining details on the implementation of the proposed phrase classification strategy are given in the next section.

\subsection{Implementation}

The computation of the class membership function derived in the previous section requires the probability mass functions $p_{F \mid M}(f \mid M=m)$ and $p_{M}(m)$ for all pitch levels $f$ and makamlar $m$. In an idealized case, these probabilities would be expected to govern the frequency of occurrence of all notes at the various pitch levels observed across the whole of makam music. In reality, however, these probabilities are not available and have to be estimated from sample makam music pieces.

In this work, we have estimated the probabilities $p_{F \mid M}(f \mid M=m)$ and $p_{M}(m)$ from the symbolic database of makam music pieces described in Section 3. Specifically, for $p_{F \mid M}(f \mid M=m)$, we have collected the frequency of the notes at a given pitch $f$ in all pieces in our database composed in the makam $m$ via

$$
p_{F \mid M}(f \mid M=m) \approx \frac{1}{Z} \sum_{\left(f^{\prime}, d^{\prime}\right) \text { in } D_{m}} \mathbf{1}\left(f=f^{\prime}\right)
$$

where the summation is carried out over all notes observed in pieces written in makam $\mathrm{m}$ in the database denoted by $D_{m}, Z$ is the count of all such notes given by

$$
Z=\sum_{\left(f^{\prime}, d^{\prime}\right) \text { in } D_{m}} 1,
$$

and where the function $\mathbf{1}(\cdot)$ returns 1 whenever its argument holds and 0 otherwise.

As for the makam prior probability distribution $p_{M}(m)$, we have used two different methods to be used in the computation of the membership function alternatives. Since $\mathbf{M}_{f}(s)$ and $\mathbf{M}_{f, d}(s)$ require the makam prior probabilities over the phrases, we have computed $p_{M}(m)$ via

$$
p_{M}(m) \approx \frac{1}{Z^{\prime}} \sum_{s \text { in } D_{m}} 1
$$

with

$$
Z^{\prime}=\sum_{m} \sum_{s \text { in } D_{m}} 1
$$

to calculate the corresponding discriminant functions. Note that in this way, $p_{M}(m)$ simply counts the number of phrases in pieces written in the makam $m$ divided by the total number of phrases in the database. For $\mathbf{M}_{f}^{\text {note }}(s), \mathbf{M}_{f, d}^{\text {note }}(s), \mathbf{M}_{f}^{\text {ave }}(s)$, and $\mathbf{M}_{f, d}^{\text {ave }}(s)$, however, we have used

$$
p_{M}(m) \approx \frac{1}{Z^{\prime \prime}} \sum_{\left(f^{\prime}, d^{\prime}\right) \text { in } D_{m}} 1
$$

with

$$
Z^{\prime \prime}=\sum_{m} \sum_{\left(f^{\prime}, d^{\prime}\right) \text { in } D_{m}} 1
$$

as these membership functions require the makam prior probabilities over the notes due to their specific formulation. 
Training:
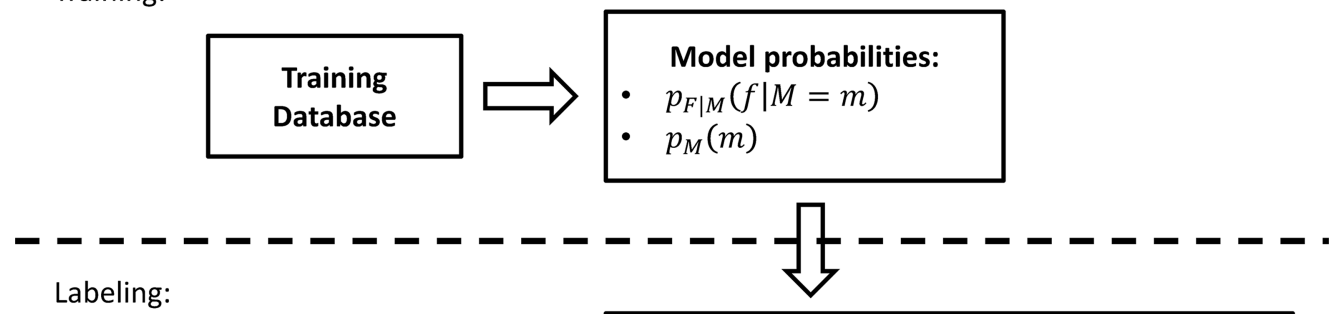

Labeling:

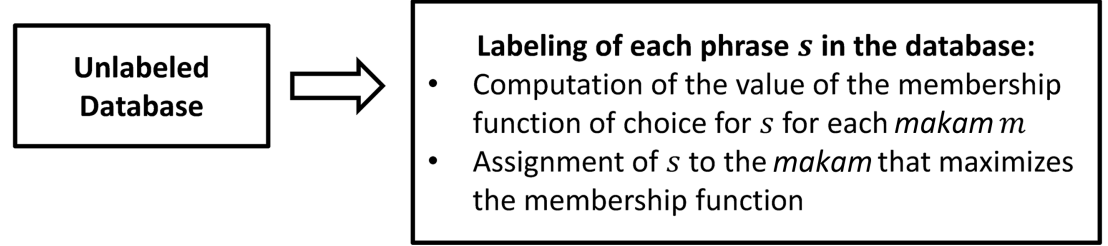

Figure 4. Illustration of the labelling framework. The probability mass functions $p_{F \mid M}(f \mid M=m)$ and $p_{M}(m)$ are calculated using the makam associations of the phrases in the symbolic makam music database available for training. These probabilities are then used to evaluate the membership function on the phrase in question for labelling, assigned to the makam maximizing the membership function.

\subsection{Melodic progression analysis of individual pieces}

Our melodic progression analysis method assumes a scenario where symbolic data of a new piece of makam music not in the database is to be analysed using the information gathered from the database. We further assume that the new piece is already divided into a succession of phrases, either manually by an expert or automatically via a melodic segmentation algorithm (such as LBDM (Local Boundary Detection Model), see Cambouropoulos 2006), leaving the phrase segmentation issue beyond the scope of this study. The melodic progression analysis of the new piece is then carried out by first computing the discriminant of the selected membership function for each phrase $s$ in the new piece and assigning $s$ to the makam that maximizes it, and returning the sequence of makam assignments corresponding to each successive phrase of the piece. The discriminant for the selected membership function is computed according to the definitions of Section 4.1 using the probability measures estimated from the symbolic makam music database described in Section 3 according to the formulas given in Section 4.2. This procedure is illustrated in Figure 4. The result of the procedure for a given piece, then, is a time sequence of makamlar, indicating which makamlar the piece in consideration visits as melodic contour progresses.

The question of which membership function to use is related to the respective accuracies in separating the phrases observed in the pieces written in the different makamlar. As a result of a general intuition obtained from makam music theory and communication with masters, we expect at least half of the phrases to be mapped to the makam of the piece. In addition, it is expected that the makam of a piece is introduced specifically in the beginning of the melodic progression (Öztürk 2011); hence the first phrases should generally be mapped to the makam of the piece as well. These considerations make it clear that the set of phrases observed in different makamlar may contain significant overlaps, requiring a probabilistic characterization of the statistical structure linking the phrases to the different makamlar rather than a blind classification strategy. Indeed, the membership functions described in Section 4.1 are designed to capture this statistical structure, allowing us to separate the phrases that are characteristic of a makam from the others that have been borrowed from other makamlar during the melodic progression of a piece through a decomposition of the makam posterior probability. Still, the performance of any recognition method working towards 
that end must be evaluated by the rate at which the phrases associated with a given makam are mapped to that makam, while it is clear that the performance cannot be maximal as the borrowed phrases are not expected to be mapped to the makam of the piece in which they occur.

We have determined these rates by setting up a leave-one-out cross validation experiment using the pieces in our database as follows.

- For each piece in the database, do:

- Revise the computation of the probability mass functions $p_{F \mid M}(f \mid M=m)$ and $p_{M}(m)$ to exclude the phrase and the note data of the current piece.

- For each phrase $s$ in the current piece, do:

- Compute the discriminant of the selected makam membership function for $s$.

- Assign $s$ to the makam that maximizes the discriminant function and record this assignment.

- Compute the confusion matrix for all makamlar by contrasting the makam assignments of each phrase to the makam of the corresponding piece.

The procedure above was repeated separately for each membership function $\mathbf{M}_{f}(s), \mathbf{M}_{f, d}(s)$, $\mathbf{M}_{f}^{\text {note }}(s), \mathbf{M}_{f, d}^{\text {note }}(s), \mathbf{M}_{f}^{\text {ave }}(s)$, and $\mathbf{M}_{f, d}^{\text {ave }}(s)$, and the resulting confusion matrices were calculated that determined the counts of phrases observed in pieces written in makam $m$ and assigned to makam $m^{\prime}$ for all makam pairs $m$ and $m^{\prime}$. The accuracies in makam assignment for the different membership functions were then computed from these confusion matrices via $F$-measures computed using precision and recall rates calculated separately for each makam on a one-againstall manner. Specifically, for makam $m$, the precision and recall rates $R^{\text {precision }}$ and $R^{\text {recall }}$ were calculated via

$$
R_{m}^{\text {precision }}=\frac{\sum_{s} \mathbf{1} \text { ("s } s \text { belonged to } \text { makam } m \text { and was assigned to } m \text { ") }}{\sum_{s} \mathbf{1}(\text { " } s \text { was assigned to makam } m \text { ") }}
$$

and

$$
R_{m}^{\text {recall }}=\frac{\sum_{s} \mathbf{1} \text { ("s } s \text { belonged to makam } m \text { and was assigned to } m \text { ") }}{\sum_{s} \mathbf{1} \text { ("s belonged to } \text { makam } m \text { ") }},
$$

respectively. The accuracy of the membership function alternatives were then determined by the $F$-measures calculated by

$$
\mathbf{F}_{m}=2 \frac{R_{m}^{\text {precision }} R_{m}^{\text {recall }}}{R_{m}^{\text {precision }}+R_{m}^{\text {recall }}}
$$

separately for each makam $m$.

\section{Results and discussion}

In this section, we present the experiment results for the proposed phrase recognition strategy on the symbolic database of makam music described in Section 3. The experiments entailed first calculating the membership functions $\mathbf{M}_{f}(s), \mathbf{M}_{f, d}(s), \mathbf{M}_{f}^{\text {note }}(s), \mathbf{M}_{f, d}^{\text {note }}(s), \mathbf{M}_{f}^{\text {ave }}(s)$, and $\mathbf{M}_{f, d}^{\text {ave }}(s)$ derived in the previous section separately for the phrases in each piece in a leave-one-out formalism. The results of the corresponding phrase assignment rules were then recorded in a global confusion matrix to reflect both the original makam of the piece in which the phrase occurred and the makam to which the phrase was assigned. The leave-one-out framework was employed by omitting all the phrases of a piece out of the dataset when computing the probability mass 
Table 3. $F$-measures observed for the phrase assignments obtained using the membership functions $\mathbf{M}_{f}, \mathbf{M}_{f, d}, \mathbf{M}_{f}^{\text {note }}, \mathbf{M}_{f, d}^{\text {note }}, \mathbf{M}_{f}^{\text {ave }}$, and $\mathbf{M}_{f, d}^{\text {ave }}$. The functions $\mathbf{M}_{f}^{\text {note }}, \mathbf{M}_{f, d}^{\text {note }}, \mathbf{M}_{f}^{\text {ave }}$, and $\mathbf{M}_{f, d}^{\text {ave }}$ failed to assign any phrase to makamlar Beyati and Uşşak, preventing the computation of an $F$-measure.

\begin{tabular}{lcccccc}
\hline & $\mathbf{M}_{f}$ & $\mathbf{M}_{f, d}$ & $\mathbf{M}_{f}^{\text {note }}$ & $\mathbf{M}_{f, d}^{\text {note }}$ & $\mathbf{M}_{f}^{\text {ave }}$ & $\mathbf{M}_{f, d}^{\text {ave }}$ \\
\hline Acemaşiran & 0.5863 & 0.6168 & 0.3608 & 0.3834 & 0.2896 & 0.3202 \\
Beyati & 0.0909 & 0.0823 & - & - & - & - \\
Buselik & 0.6997 & 0.6889 & 0.2900 & 0.1404 & 0.3514 & 0.2513 \\
Hicaz & 07823 & 0.7736 & 0.6732 & 0.6558 & 0.5903 & 0.5615 \\
Hicazkar & 0.5826 & 0.5933 & 0.5655 & 0.5403 & 0.5166 & 05228 \\
Hüseyni & 0.4237 & 0.4209 & 0.3951 & 0.3687 & 0.2631 & 0.1631 \\
Hüzzam & 0.5927 & 0.5794 & 0.5563 & 0.5373 & 0.5626 & 0.5291 \\
Kürdilihicazkar & 0.7773 & 0.7554 & 0.7063 & 0.6925 & 0.6637 & 0.6690 \\
Mahur & 0.6782 & 0.7057 & 0.4590 & 0.3509 & 0.5850 & 0.4408 \\
Muhayyer & 0.3226 & 0.3108 & 0.0630 & 0.0484 & 0.0760 & 0.0286 \\
Nihavent & 0.6220 & 0.5821 & 0.1948 & 0.1111 & 0.0221 & 0.0294 \\
Rast & 0.3366 & 0.3689 & 0.0858 & 0.0862 & - & 0.0095 \\
Saba & 0.6983 & 0.6610 & 0.3693 & 0.1890 & 0.6821 & 0.6240 \\
Segah & 0.6242 & 0.5913 & 0.2065 & 0.2575 & 0.3207 & 0.3401 \\
Uşşak & 0.2584 & 0.2535 & - & - & - & - \\
Average & 0.5384 & 0.5323 & 0.3789 & 0.3355 & 0.4103 & 0.3453 \\
\hline
\end{tabular}

functions $p_{M}(m)$ and $p_{F \mid M}(f \mid M=m)$ to calculate the membership functions and the subsequent makam assignment of each phrase in that piece. This ensured that the knowledge of the piece in question did not affect the learned probability distributions from the music data in any way. As a result, the probability distribution estimates computed separately at each step of the leave-oneout procedure deviated slightly from the global estimates obtained from the entire dataset shown in Figures 5 and 6.

Following the computation of the confusion matrices produced by the membership function alternatives, we have calculated the $F$-measures to assess the rate of mapping the phrases in each makam separately, as well as an average $F$-measure via the arithmetic average of the individual $F$-measures obtained for each of the 15 makamlar represented in our symbolic makam music database. The results in Table 3 show that among the membership functions constructed in the previous section, $\mathbf{M}_{f}(s)$ resulted in the highest average $F$-measure across all makamlar, attesting to the validity of decomposing the makam posterior distributions across the pitch values of the notes making up a phrase. We have also observed that an $F$-measure could not be computed for the functions $\mathbf{M}_{f}^{\text {note }}, \mathbf{M}_{f, d}^{\text {note }}, \mathbf{M}_{f}^{\text {ave }}$, and $\mathbf{M}_{f, d}^{\text {ave }}$ for the makamlar Beyati and Uşşak. Further investigations revealed that the assignment rules based on these membership functions failed to assign any phrase to these makamlar, preventing the computation of a precision rate as well as a subsequent $F$-measure. Similar observations were reported by previous makam classification studies (such as Ünal, Bozkurt, and Karaosmanoğlu 2014; Gedik and Bozkurt 2010) since the pitch class distributions of Beyati and Uşşak makamlar are very similar (as can be seen in Figure 6), and from music theory we know that Rast and Hüseyni pieces may include a large amount of Uş̧ak makam phrases. It is clear that new features are needed to capture the characteristics that differentiate specifically these two makamlar.

As the next step, we have repeated the leave-one-out experiments by assuming a uniform prior makam distribution $p_{M}(m)$ instead of the ones computed from the symbolic makam music dataset. The resulting $F$-measures in Table 4 show that a uniform makam prior probability allowed assigning more phrases to the less prominent makamlar such as Beyati and Uşşak, albeit with no discernible improvement in the best classification performance achieved by the membership function $\mathbf{M}_{f}$ in the associated $F$-measures.

The confusion matrix obtained using the best-performing membership function, $\mathbf{M}_{f}$, shows that a large part of the phrases have been successfully assigned to their actual makam (Table 5). 
It is also clear that some makamlar were recognized relatively easily, such as Kürdilihicazkar, Hicaz, and Saba, while others, such as Beyati and Uş̧̧ak were difficult to recognize. This is an
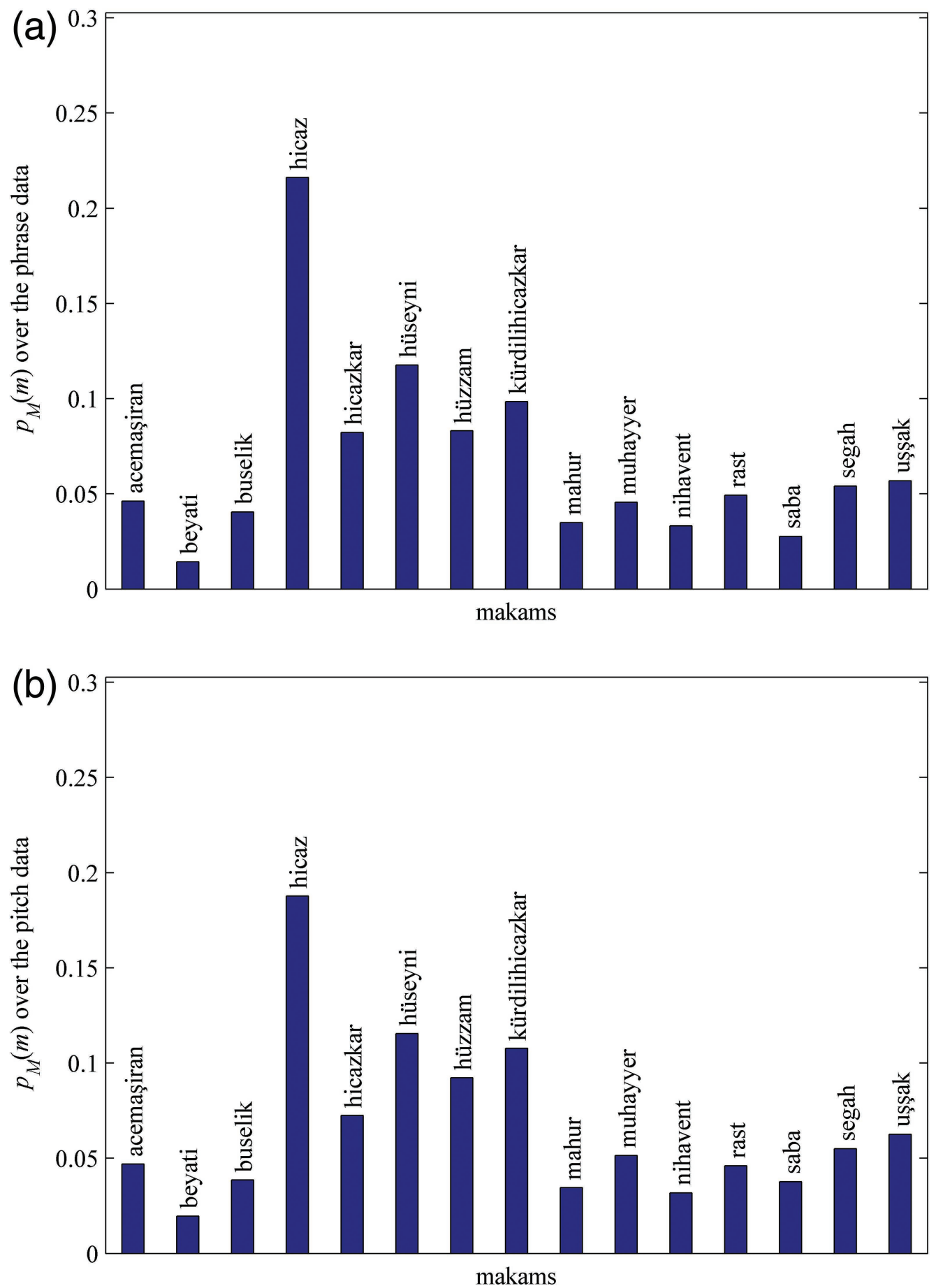

Figure 5. Probability mass function $p_{M}(m)$ pertaining to the phrase (a) and pitch (b) data estimated from the entire symbolic makam music database. 

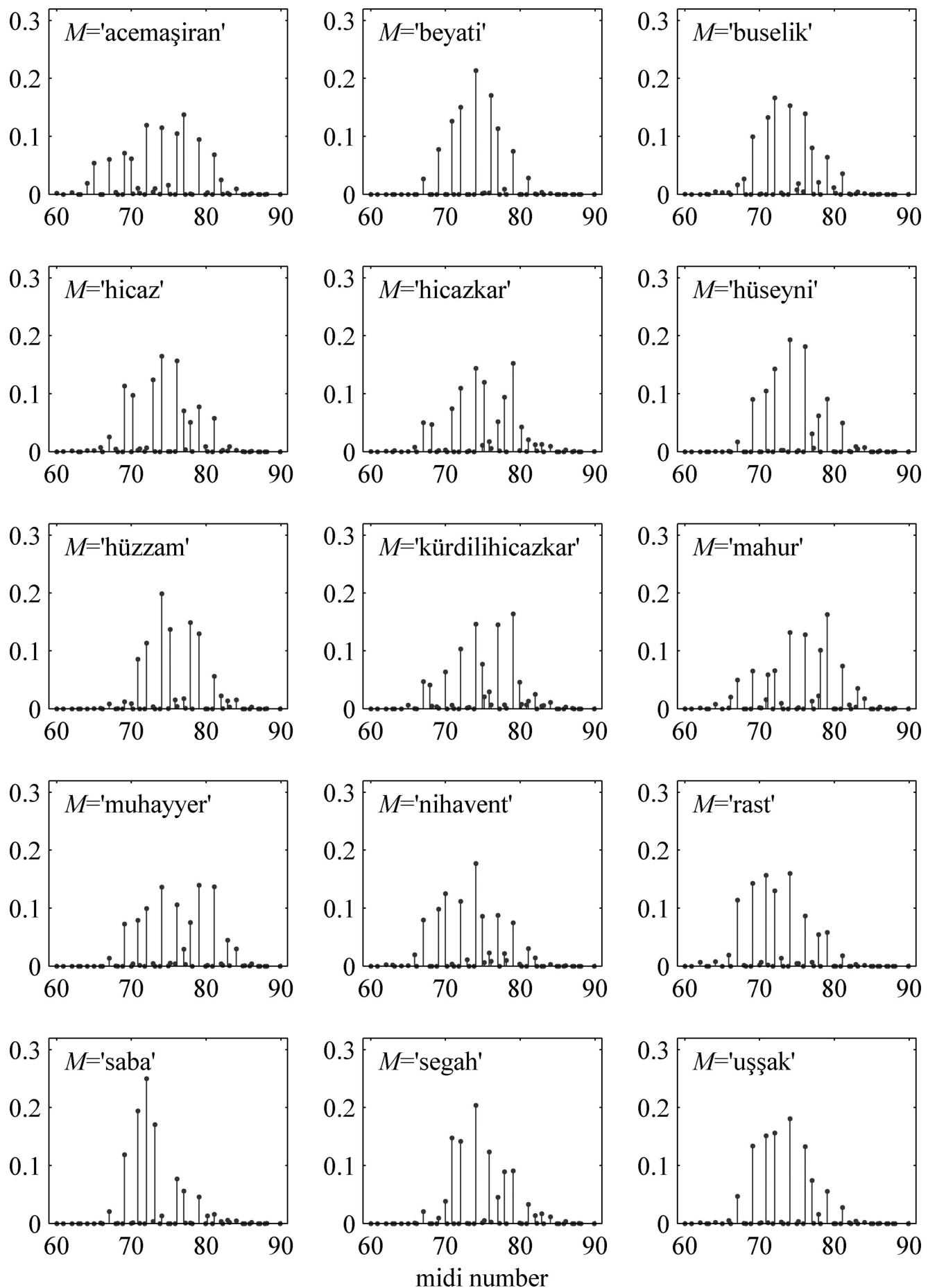

Figure 6. The probability mass functions of the pitch values $p_{F \mid M}(f \mid M=m)$ computed from the entire symbolic makam music database for each makam $m$. The pitch values are displayed in the horizontal axis, expressed by the respective fractional MIDI numbers associated with the makam music. 
Table 4. $\quad F$-measures observed for the phrase assignments obtained using the membership functions $\mathbf{M}_{f}, \mathbf{M}_{f, d}, \mathbf{M}_{f}^{\text {note }}, \mathbf{M}_{f, d}^{\text {note }}, \mathbf{M}_{f}^{\text {ave }}$, and $\mathbf{M}_{f, d}^{\text {ave }}$ under the assumption of a uniform makam prior distribution. Note the identity of the first and third as well as the second and fourth columns.

\begin{tabular}{lcccccc}
\hline & $\mathbf{M}_{f}$ & $\mathbf{M}_{f, d}$ & $\mathbf{M}_{f}^{\text {note }}$ & $\mathbf{M}_{f, d}^{\text {note }}$ & $\mathbf{M}_{f}^{\text {ave }}$ & $\mathbf{M}_{f, d}^{\text {ave }}$ \\
\hline Acemaşiran & 0.5844 & 0.5544 & 0.5844 & 0.5544 & 0.5074 & 0.4651 \\
Beyati & 0.0891 & 0.1017 & 0.0891 & 0.1017 & 0.0928 & 0.1049 \\
Buselik & 0.7005 & 0.8130 & 0.7005 & 0.6813 & 0.6341 & 0.6443 \\
Hicaz & 0.7535 & 0.7458 & 0.7535 & 0.7458 & 0.7187 & 0.7047 \\
Hicazkar & 0.5858 & 0.5982 & 0.5858 & 0.5982 & 0.6193 & 0.5983 \\
Hüseyni & 0.2615 & 0.3026 & 0.2615 & 0.3026 & 0.2309 & 0.2880 \\
Hüzzam & 0.5977 & 0.5773 & 0.5977 & 0.5773 & 0.5488 & 0.5283 \\
Kürdilihicazkar & 0.7694 & 0.7751 & 0.7694 & 0.7751 & 0.6378 & 0.5669 \\
Mahur & 0.6752 & 0.6895 & 0.6752 & 0.6895 & 0.5859 & 0.6316 \\
Muhayyer & 0.3001 & 0.2984 & 0.3001 & 0.2984 & 0.3004 & 0.3018 \\
Nihavent & 0.6352 & 0.6232 & 0.6352 & 0.6232 & 0.5078 & 0.4667 \\
Rast & 0.3622 & 0.3628 & 0.3622 & 0.3628 & 0.3662 & 0.3226 \\
Saba & 0.6600 & 0.6194 & 0.6600 & 0.6194 & 0.3720 & 0.4005 \\
Segah & 0.6254 & 0.6089 & 0.6254 & 0.6089 & 0.5614 & 0.5551 \\
Uşşak & 0.2118 & 0.2362 & 0.2118 & 0.2362 & 0.0965 & 0.1388 \\
Average & 0.5208 & 0.5183 & 0.5208 & 0.5183 & 0.4520 & 0.4478 \\
\hline
\end{tabular}

Table 5. The confusion matrix obtained by the membership function $\mathbf{M}_{f}$ using the probability estimates calculated from the symbolic makam music dataset separately at each step of the leave-one-out procedure.

Predicted makam

\begin{tabular}{|c|c|c|c|c|c|c|c|c|c|c|c|c|c|c|c|c|}
\hline True makam & 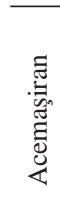 & 志 & 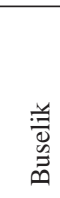 & : & 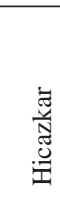 & 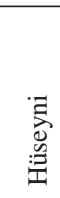 & $\begin{array}{l}\text { E్ } \\
\text { N } \\
\text { : }\end{array}$ & 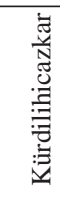 & 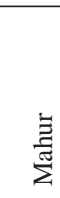 & 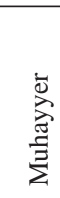 & 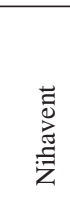 & $\begin{array}{l}\tilde{\tilde{z}} \\
\tilde{\approx}\end{array}$ & 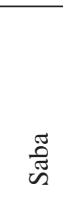 & 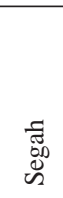 & 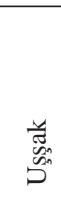 & 퓽 \\
\hline Acemaşiran & 192 & 36 & 6 & 26 & 4 & 21 & 7 & 7 & 0 & 24 & 25 & 0 & 23 & 0 & 2 & 373 \\
\hline Beyati & 10 & 12 & 0 & 10 & 0 & 11 & 2 & 2 & 0 & 5 & 0 & 6 & 0 & 0 & 57 & 115 \\
\hline Buselik & 9 & 6 & 205 & 42 & 2 & 24 & 15 & 5 & 4 & 7 & 0 & 3 & 0 & 4 & 0 & 326 \\
\hline Hicaz & 11 & 4 & 15 & 1328 & 4 & 92 & 28 & 18 & 34 & 132 & 0 & 73 & 3 & 0 & 1 & 1743 \\
\hline Hicazkar & 11 & 0 & 0 & 12 & 32 & 9 & 210 & 68 & 0 & 3 & 10 & 1 & 7 & 8 & 3 & 663 \\
\hline Hüseyni & 2 & 21 & 0 & 88 & 0 & 379 & 17 & 0 & 11 & 133 & 0 & 63 & 12 & 0 & 223 & 949 \\
\hline Hüzzam & 3 & 4 & 0 & 11 & 19 & 19 & 457 & 8 & 7 & 23 & 0 & 33 & 2 & 63 & 21 & 670 \\
\hline Kürdilihicazkar & 8 & 0 & 1 & 7 & 63 & 1 & 22 & 623 & 0 & 3 & 33 & 11 & 0 & 22 & 0 & 794 \\
\hline Mahur & 2 & 0 & 27 & 14 & 0 & 32 & 1 & 2 & 176 & 14 & 0 & 11 & 0 & 2 & 0 & 281 \\
\hline Muhayyer & 0 & 4 & 3 & 25 & 2 & 65 & 18 & 0 & 1 & 150 & 0 & 26 & 5 & 9 & 60 & 368 \\
\hline Nihavent & 5 & 0 & 0 & 8 & 14 & 1 & 8 & 60 & 4 & 1 & 153 & 3 & 0 & 11 & 0 & 268 \\
\hline Rast & 1 & 1 & 1 & 36 & 1 & 96 & 20 & 0 & 1 & 15 & 3 & 156 & 7 & 4 & 55 & 397 \\
\hline Saba & 11 & 0 & 0 & 17 & 5 & 7 & 1 & 7 & 0 & 7 & 0 & 4 & 162 & 1 & 1 & 223 \\
\hline Segah & 0 & 4 & 0 & 2 & 4 & 14 & 57 & 9 & 0 & 23 & 0 & 31 & 9 & 255 & 28 & 436 \\
\hline Uşşak & 17 & 57 & 2 & 26 & 0 & 69 & 9 & 0 & 0 & 22 & 0 & 109 & 11 & 2 & 135 & 459 \\
\hline Total & 282 & 149 & 260 & 1652 & 439 & 840 & 872 & 80 & 238 & 562 & 224 & 50 & 41 & 381 & 586 & 8065 \\
\hline
\end{tabular}

expected result when the scales of the makamlar and the distributions in Figure 5 are considered. Beyati and Uşşak share the same scale that is very close to that of Hüseyni, Muhayyer, and Rast.

The time course of the makam assignments of the phrases in three selected pieces from the symbolic makam music database shown in Figure 7 illustrates the varying use of different makamlar throughout a makam music piece. These examples illustrate a general characteristic of the makam music, to start a piece in its designated makam, and visit other makamlar. We have chosen representative examples of varying degrees of match with the main makam of the piece. 

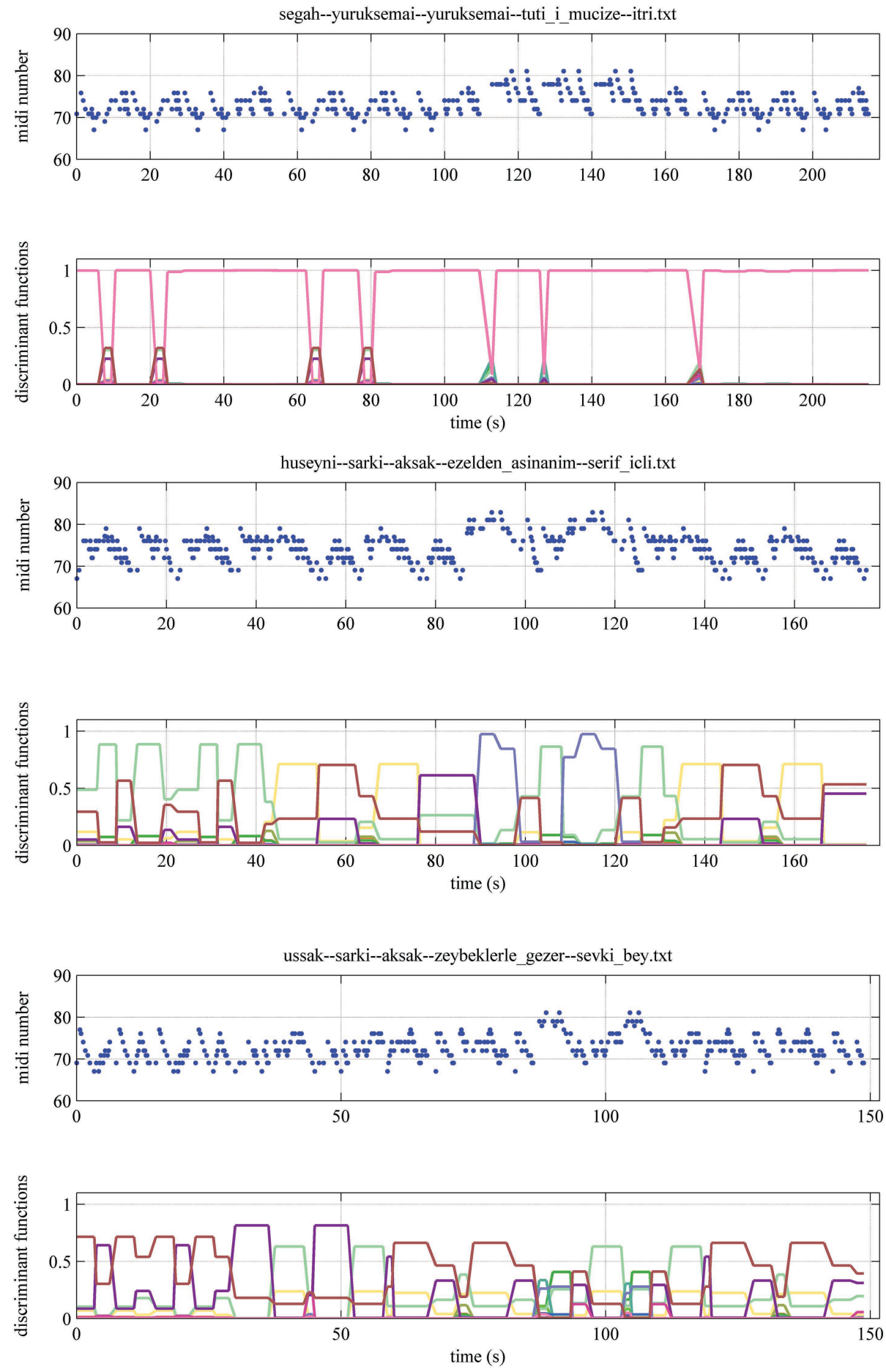

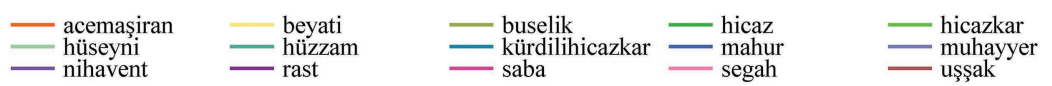

Figure 7. Time course of the makam assignments of the phrases for three pieces in the symbolic makam music database as determined using the best performing classification rule $\mathbf{M}_{f}$. 
Table 6. $F$-measures observed for the assignment of the first four phrases of each piece into the different makamlar. Only the results obtained using the makam priors derived from the symbolic makam music database are shown.

\begin{tabular}{lcccccc}
\hline & $\mathbf{M}_{f}$ & $\mathbf{M}_{f, d}$ & $\mathbf{M}_{f}^{\text {note }}$ & $\mathbf{M}_{f, d}^{\text {note }}$ & $\mathbf{M}_{f}^{\text {ave }}$ & $\mathbf{M}_{f, d}^{\text {ave }}$ \\
\hline Acemaşiran & 0.6182 & 0.6230 & 0.2326 & 0.2667 & 0.1053 & 0.1500 \\
Beyati & 0.0909 & 0.2005 & - & - & - & - \\
Buselik & 0.8387 & 0.8387 & 0.2162 & 0.2222 & 0.4091 & 02162 \\
Hicaz & 0.8240 & 0.8000 & 06250 & 0.6164 & 0.5357 & 0.5037 \\
Hicazkar & 0.6250 & 0.6383 & 0.6667 & 0.5610 & 0.5000 & 0.4935 \\
Hüseyni & 0.5100 & 0.5049 & 0.3571 & 0.3381 & 0.2029 & 0.1354 \\
Hüzzam & 0.6867 & 0.6747 & 0.6333 & 0.6129 & 0.6215 & 0.6310 \\
Kürdilihicazkar & 0.8000 & 0.7871 & 0.7732 & 0.7411 & 0.7437 & 0.6860 \\
Mahur & 0.6923 & 0.7200 & 0.4444 & 0.4000 & 0.6977 & 0.5641 \\
Muhayyer & 0.5686 & 0.5657 & 0.2041 & 0.1277 & 0.2041 & 0.0870 \\
Nihavent & 0.5778 & 0.5455 & 0.1290 & 0.1333 & - & - \\
Rast & 0.3495 & 0.3894 & 0.1455 & 0.1455 & - & 0.0800 \\
Saba & 0.8966 & 0.8475 & 0.5263 & 0.3030 & 0.8333 & 0.8571 \\
Segah & 0.5957 & 0.5714 & 0.3188 & 0.3030 & 0.3235 & 0.2857 \\
Uşşak & 0.3478 & 0.3148 & - & - & - & - \\
Average & 0.6015 & 0.6021 & 0.4056 & 0.3670 & 0.4706 & 0.3908 \\
\hline
\end{tabular}

The first example is a short piece considered to be very representative of makam Segah in the music circles. We observe that the progression mainly stays in makam Segah as expected.

The second example is in the popular Şarkı form in makam Hüseyni. Typically, makam Hüseyni includes phrases in three main overlapping regions of the pitch space: the lower half of the scale (where some phrases ending on the tonic are considered to be Uşşak phrases), the midregion of the scale emphasizing the dominant note $\mathrm{E}$ (where phrases would be mostly mapped to makam Hüseyni) and a higher half of the scale (where phrases emphasizing the upper tonic are mapped to makam Muhayyer). We observe on the figure that the makam mappings are in line with the above expectation rooted in theory (Özkan 2006) and descriptions by masters (private communication with Ruhi Ayangil and Reha Sağbaş): melodic progression starts in the midregion where phrases are mainly mapped to makam Hüseyni (here the expectation that the initial phrases are mapped to the main makam - Öztürk 2011 - is also satisfied). Then, in the 45-90 seconds region, the melody tends towards the tonic and the labelled makamlar are Beyati, Uşşak, and Rast (these classes have a large overlap). In the 90-120 seconds region, phrases emphasize the upper tonic and the makam is labelled as Muhayyer. Finally, the progression ends with the lower tonic with Beyati and Uşşak labels as before.

The third example is in makam Uşşak and the mappings vary among the classes Uşşak, Rast, and Hüseyni. Since the overlap of these classes is very high, this part of the data needs a further detailed study with new features defining the phrases and in-depth musicological research on how strict the boundaries between phrases of these classes can be drawn. A large part of the "confusions" in our results fall into this category. This is clearly observed in the confusion matrices, with phrases from makamlar Uşşak, Beyati, Rast, and Hüseyni being cross-mapped within the group of these four makamlar.

This temporal organization also suggests a greater accuracy in the mapping of the beginning phrases of a piece into the corresponding makam. In order to test this observation, we have calculated the $F$-measures for each makam over the first four phrases of each piece. The results in Table 6 show that the assignment of these phrases into the different makamlar is indeed more accurate, with greater $F$-measures achieved for each makam, suggesting that the beginning phrases tend to adhere more strongly to the characteristics of the makam within which the piece has been composed. This result is also consistent with the postulates of recent musicological studies (Öztürk 2011). 


\section{Conclusions}

This paper addressed the challenge of designing an automatic analysis method for matching melodic phrases to makamlar with an output of a representation of context change within pieces, for the first time in the literature. There is no agreed upon methodology to perform the task by humans, hence we used engineering methods to check the consistency of our results and study a few individual samples to observe if the analysis results match the descriptions in makam music studies.

The proposed automatic analysis method is based on Bayesian learning and uses a makam membership function also defined in this work. Several versions of the membership function have been tested and the highest accuracy obtained is 0.5208 . Considering that the data pool contained 199 pieces from 15 different makamlar (including very close makam classes such as Uşşak, Beyati, and Hüseyni), the rate of recognition is relatively high. A higher accuracy of 0.6021 is obtained when the system is tested on the first four phrases of the pieces. This result is in line with musicological works (Öztürk 2011) that claim the main makam is specifically expressed at the beginning of the piece.

In this work, we used membership functions based on pitch distributions. The system is open to extension to use several additional features to better represent the properties of musical phrases. It is among our future goals to perform an extensive study with the masters on the outputs of our system to collect expert knowledge and define new features that would increase the robustness of the system. We will specifically consider the main difficulty our system faces in recognition, namely mapping of phrases to classes with very close pitch distributions such as Uşşak, Beyati, and Hüseyni. This will require both an in-depth musicological study for these makamlar and an experimental study on how experts label phrases taken out of context in these close makamlar, and how they draw boundaries between these classes.

Recognition accuracies and analysis of individual examples show that the proposed methodology has a verified potential in automatic analysis of makam music pieces on large databases. In our interviews with the experts of this music, they often stated that an analysis of a large repertoire, and gathering more statistical data, could possibly lead to a better understanding of the makam concept. Automatic analysis can potentially provide us with the chance to gather information otherwise impossible because of the required amount of manual work.

In order to address this challenge, we developed a segmented phrase database for the first time in the literature, which is publicly available upon request from the authors.

One of the drawbacks of our approach is in processing phrases that come from transposed versions of makamlar. It is possible that a piece in makam Hicaz can include transposed Hicaz phrases in the development sections as the composer expresses creativity. For these cases, our approach tends to link this phrase with the closest possible makam that includes a Hicaz (tetra/penta) chord on that note. Our future work will include analysis with dynamic features to capture such characteristics of transposed makamlar.

Part of our future work will be dedicated to exploring tools available for symbolic music analysis such as Humdrum (http://www.musiccog.ohio-state.edu/Humdrum/), music21 (http://web.mit.edu/music21/), Jazzomat (http://lemming.hfm-weimar.de/jazzomat/), and Midi Toolbox (https://www.jyu.fi/hum/laitokset/musiikki/en/research/coe/materials/miditoolbox). Moving in that direction necessitates several format conversions (which are in progress) as well as a study on musical concepts since most of the tools available are developed for Western music.

\section{Acknowledgements}

We thank Thomas Fiore for his incredible editorial work on this article. This work is supported by the Scientific and Technological Research Council of Turkey, TUBITAK, Grant [112E162]. 


\section{References}

Arel, H. S. 1968. Türk Musikisi Nazariyatı [The Theory of Turkish Music]. İstanbul: Hüsnütabiat matbaas1.

Ay, G., and L. B. Akkal eds. 2008. Türk Müziğinde Uygulama-Kuram Sorunlarıve Çözümleri - Uluslararası Çăgrılı Kongre Bildiriler Kitabı [Problems and Solutions for Practice and Theory in Turkish Music International Invited Congress Proceedings]. İstanbul: İstanbul Büyükşehir Belediyesi Yayınları.

Ayangil, R. 2001. “21. Yüzyıl Eşiğinde Türkiyede Müzik Kuramı Çalışmaları.” Musikişinas 5: 72-81.

Bozkurt, B., O. Yarman, M.K. Karaosmanoğlu, and C. Akkoç. 2009. "Weighing Diverse Theoretical Models on Turkish Maqam Music Against Pitch Measurements: A Comparison of Peaks Automatically Derived from Frequency Histograms with Proposed Scale Tones." Journal of New Music Research 38 (1): 45-70.

Bozkurt, B., R. Ayangil, and A. Holzapfel. 2014. "Computational Analysis of Turkish Makam Music: Review of State-of-the-Art and Challenges." Journal of New Music Research 43 (1): 3-23.

Cambouropoulos, E. 2006. "Musical Parallelism and Melodic Segmentation: A Computational Approach." Music Perception 23 (3): 249-268.

Can, M. C. 1993. "Türk müziğinde makam kavramı üzerine bir inceleme.” MA diss., Erciyes University.

Conklin, D. 2001. "Representation and Discovery of Multiple Viewpoint Patterns." Presented at the International Computer Music Conference, Havana, Cuba.

Conklin, D. 2010. "Discovery of Distinctive Patterns in Music." Intelligent Data Analysis 14 (5): 547-554.

Çelik, B. B. 2001. “Hızır bin Abdullah'ın Kitabü’l Edvar'ıve Makamların İncelenmesi.” MA diss. Marmara University.

Çevikoğlu, T. 2007. "Klasik Türk Müziğinin bugünkü sorunları.” Presented at the International Congress of Asian and North African Studies (Icanas 38'), Ankara, Turkey.

Ederer, E. B. 2011. “The Theory and Praxis of Makam in Classical Turkish Music 1910-2010.” PhD diss. University of California.

Elsner, J., and R.P. Pennanen, eds. 1997. The Structure and Idea of Maqam Historical Approaches. Tampere: DFT Publications (University of Tampere).

Eroy, O. 2010. "Tekirdağ Bölgesi Çingene Müziklerinde Kullanılan Ezgi Yapılarının İncelenmesi.” MS diss. Kirıkkale University.

Gedik, A. C., C. Işıkhan, A. Alpkoçak, and Y. Özer. 2005. "Automatic Classification of 10 Turkish Makams." Presented at the International Congress on Representation in Music \& Musical Representation, İstanbul, Turkey.

Gedik, A. C., and B. Bozkurt. 2010. "Pitch-frequency Histogram-based Music Information Retrieval for Turkish Music." Signal Processing 90 (4): 1049-1063.

Gönül, M. 2010. "Nevres Bey'in Ud Taksimleri Analizi ve Ud Eğitimine Yönelik Alıştırmaların Oluşturulması." PhD diss. Selçuk University.

Gündüz, G., and U. Gündüz. 2005. "The Mathematical Analysis of the Structure of Some Songs." Physica A: Statistical Mechanics and its Applications 357 (3-4): 565-592.

Ioannidis, L., E. Gómez, and P. Herrera. 2011. "Tonal-based Retrieval of Arabic and Middle-East Music by Automatic Makam Description." Presented at the 9th International Workshop on Content-Based Multimedia Indexing, Madrid, Spain.

Karaosmanoğlu, M. K. 2012. "A Turkish Makam Music Symbolic Database for Music Information Retrieval: SymbTr." Poster presented at the Conference of International Society for Music Information Retrieval (ISMIR), Porto, Portugal.

Kılınçarslan, H. 2006. "Dede Efendi'nin Hüzzam Mevlevi Ayininin Makam, Usul ve Ezgisel Yönden İncelenmesi." MA diss. Selçuk University.

Lartillot, O., and M. Ayari. 2009. "Segmentation of Tunisian Modal Improvisation: Comparing Listeners' Responses with Computational Predictions." Journal of New Music Research 38 (2): 117-127.

Meredith, D., K. Lemstrom, and G. Wiggins. 2002. "Algorithms for Discovering Repeated Patterns in Multidimensional Representations of Polyphonic Music." Journal of New Music Research 31 (4): 321-245.

Müezzinoğlu, A. 2004. “Zeybeklerin SQL Sorgulama Analizi.” MA diss. Gazi University.

Özkan, İ. H. 2006. Türk Musikisi Nazariyattve Usulleri Kudüm Velveleleri. İstanbul: Ötüken Neşriyat.

Öztürk, O. M. 2011. "Turkish Modernisation and Makam Concept: Some Determinations on Two Musical Systems." ICTM (International Council for Traditional Music) Yearbook.

Powers, H. S., and F. Wiering. n.d. "Mode §1: The Term. Grove Music Online." Edited by Deane Root. Accessed March 21, 2013. http://www.oxfordmusiconline.com/

Rolland, P. 1999. "Discovering Patterns in Musical Sequences." Journal of New Music Research 28 (4): 334-350. 
Sümbüllü, H. T., and A. Albuz. 2011. "Türk sanat müziği dizilerinin bilgisayar destekli makamsal analizi." Uluslararasi Insan Bilimleri Dergisi 8 (1): 145-198.

Stubbs, F. W. 1994. "The Art and Science of Taksim: An Emprical Analysis of Traditional Improvisation from 20th Century Istanbul." PhD diss. Wesleyan University.

Şentürk, S. 2011. "Computational Modeling of Improvisation in Turkish Folk Music using Variable-length Markov Models." MS diss. Georgia Institute of Technology.

Tarikci, A. 2010. "Analysis of Turkish Art Music Songs via Fractal Dimension. Physics." PhD diss. Middle East Technical University.

Ünal, E., B. Bozkurt, and M.K. Karaosmanoğlu. 2014. "A Hierarchical Approach to Makam Classification in Turkish Makam Music, Using Symbolic Data.” Journal of New Music Research 43 (1): 132-146.

Yekta, R. 1924. Musiki Nazariyatı [Music Theory]. İstanbul: Mahmut Bey Matbaas1.

Yener, S. 2004. "Bilgisayar Destekli Analiz Yoluyla Geleneksel Türk Sanat Müziği Hicaz Taksimlerinde Kalıplaşmış Ezgilerin Araştırılması.” MA diss. Gazi University.

Yener, S., and C. Aksu. 2004. "Türk Halk Müziği Ezgilerindeki Türk Müzik Dokusunun Bilgisayar Destekli Analizi.” Atatürk Üniversitesi Güzel Sanatlar Enstitüsü Dergisi 13: 124-137.

Yöre, S. 2012. "Maqam in Music as a Concept, Scale and Phenomenon." Journal of World of Turks 4 (3): 267-286. 